\title{
NEDD8-Activating Enzyme E1 Regulatory
} Subunit

National Cancer Institute

\section{Source}

National Cancer Institute. NEDD8-Activating Enzyme E1 Regulatory Subunit. NCI

Thesaurus. Code $C 95855$.

NEDD8-activating enzyme E1 regulatory subunit (534 aa, $60 \mathrm{kDa}$ ) is encoded by the human NAE1 gene. This protein plays a role in the mediation of protein neddylation. 